\title{
KOVİD-19 Kaygısının Çeşitli Değişkenler Açısından İncelenmesi
}

\author{
DOI: $10.26466 /$ opus. 943710
}

\author{
Serhat Arslan* - Savaş Karagözz ${ }^{* *}$ Nihan Arslan*** \\ ${ }^{*}$ Doç. Dr., Necmettin Erbakan Üniversitesi, Konya/Türkiye \\ E-Posta: serhat.arslan@erbakan.edu.tr \\ ORCID: 0000-0003-4422-8421 \\ ** Doç. Dr., Aksaray Üniversitesi, Aksaray/Türkiye \\ E-Posta: savaskaragoz@aksaray.edu.tr \\ ORCID: 0000-0002-4410-9214 \\ *** Doç. Dr., Necmettin Erbakan Üniversitesi, Konya /Türkiye \\ E-Posta: nihan.arslan@erbakan.edu.tr \\ ORCID: $\quad \underline{0000-0002-4410-9214}$
}

\section{Öz}

Tarihsel süreç içinde insanoğlu varolduğu günden itibaren genel tanım itibariyle afet diyebileceğimiz, savaşlar ve salgin hastalklar gibi olumsuz olaylarla karşı karşıya kalmıştır. Bu gibi durumlarda psikolojik olarak kaygı, stress, anksiyete yaşaması kaçınılmaz olmuştur. Bu çalışmada,KOVID Kayg̨ Ölçeğinin psikometrik özelliklerinin çeşitli değişkenler açısından incelenmesi amaçlanmıştır. Ölçeğin tamamı için Cronbach's $(\alpha)$ katsayısı .92 olarak bulunmuştur. KOVID Kaygı Ölçeği maddelerinin korelasyon puanlarn 63 ile .82 aralı̆̆ında değisştiği bulunmuştur. Ölçeğin doğrulayıcı faktör analizi sonucunda elde edilen uyum indeksleri; NNFI = .95, CFI =.97, IFI = $.97, \operatorname{SRMR}=.04, R M S E A=.15$. Ayrica, araştırma kapsaminda cinsiyet;eğitim durumu ve yaşanilan yer değģşkenleri arasında anlamlı düzeyde farklllklar olup olmadığı incelenmiştir. KOVID kaygı düzeyleri; cinsiyet; eğitim durumu ve yaşanılan yer değişkenleri arasında anlaml düzeyde farkllıklar olup olmadığını tespit etmek Bağmsız Gruplar t-Testi ve Anova uygulanmıştır. KOVID Kaygl düzeylerine göre erkek ve kadın katılimclar arasında anlamlı düzeyde bir farkllık olduğu anlaşılmaktadır. KOVID Kaygı düzeylerine göre katılımcların yaşanılan yer değ̆işkeni açışından anlamlı düzeyde bir farkllık olduğu anlaşılmaktadır. Ĕ̈̆itim durumları açısından araştırmaya katılan bireylerin KOVID kaygısı puan ortalamalarna ilişkin anlaml farkllık bulunmamaktadir.

Anahtar Kelimeler: KOVID-19,Kayğ,Ölçek,Ölçek Uyarlama. 


\title{
Examining the COVID-19 Anxiety in Terms of Various Variables
}

\begin{abstract}
In the historical process, human beings faced with such events as wars and epidemics. In such cases, it was inevitable that he/she would experience anxiety, stress, anxiety psychologically. In this study, it was aimed to examine the psychometric properties of the COVID Anxiety Scale in terms of various variables. Cronbach's coefficient $(\alpha)$ for the entire scale was .92. According to the results of confirmatory factor analysis, it was found that the uni-dimensional model of the scale was suitable for the Turkish sample. Compliance indices obtained as a result of confirmatory factor analysis of the scale; NNFI $=.95$, $C F I=.97, I F I=.97, S R M R=.04, R M S E A=.15$. In addition, Independent Groups t-test and Anova were applied to determine whether there were significant differences between gender, educational status and experienced location variables. There was a significant level of difference between male and female participants according to COVID Anxiety levels. There were no significant differences in the mean COVID anxiety scores of the individuals participating in the study. There were no significant differences in the mean COVID anxiety scores of the individuals participating in the study in terms of their educational status.
\end{abstract}

Keywords: COVID-19, Anxiety, Scale,Scale Adaptation. 


\section{Giriş}

Tarihsel süreç içinde insanoğlu varolduğu günden itibaren genel tanım itibariyle afet diyebileceğimiz, savaşlar ve salgın hastalıklar gibi olumsuz olaylarla karşı karşıya kalmıştır. Bu gibi durumlarda psikolojik olarak insanların kaygı, stress, anksiyete yaşaması kaçınılmaz olmuştur. İngilizce anxiety kavramına karşılık gelen kaygı "Bireylerin, toplumsal kümelerin herhangi bir güçlü istek ya da güdülerinin, gerçekleşememesi olasılığı karşısında duydukları tedirginlik"olarak tanımlanırken Türk Dil Kurumu(2021) sözlüğünde ise "Üzüntü, endişe duyulan düşünce, gam, tasa ve genellikle kötü bir şey olacakmış düşüncesiyle ortaya çıkan ve sebebi bilinmeyen gerginlik duygusu" şeklinde tanımlanmıştır. İnsan yaşamının olumsuz etkilendiği dönemlerde en çok ortaya çıkabilecek problemlerden biri kaygıdır (Atak, 2020). İnsanları sosyal, ekonomik ve psikolojik yönlerden etkileyen tarihte yaşanan önemli salgınlar; Antonine Salginı (165-180 yılları arası), 1.Veba Salgını (541-542 yılları arası); Kolera Pandemileri 1-6 (1817-1923 yılları arası), SARS (2002-2004 yılları arası); COVID 19 (2019-günümüz) (Türk, Bilgül ve Ak 2020) arasında yer almaktadır.

COVID-19 salgını, 31 Aralık 2019 tarihinde Çin' in Wuhan kentinde ortaya çıktığından beri giderek tüm dünyada yayılmaya başlayan ve insan hayatını etkisi altına alan bir pandemiye dönüşmüştür. Dünya Sağllk Örgütü tarafından 11 Mart 2020 tarihinde pandemik bir hastalık olarak ilan edilmiştir. COVID-19 sürecinin dünya geneleninde ne zaman son bulacağının bilinmemesi ve bu süreçte COVID-19 a karşı üretilen aşıların ve tıbbi tedavilerin etkililiğin tam olarak bilinmemesinin yanı sıra sıklıkla duyduğumuz sosyal mesafe, izolasyon ve karantina gibi salgınla ilgili konular, sosyal iletişimden uzak durma gibi durumlar kişilerde üzüntü, endişe, korku, öfke, kızgınlık, hayal kırıklı̆̆ı, suçluluk, çaresizlik, yalnızlık ve gerginlik gibi psikolojik rahatsızlıkların yaşanmasına neden olabilir ve olmaktadır (Ahorsu vd., 2020, s.2; Banerjee, 2020; Gencer,2020, s.1153-1173; Mamun ve Griffiths, 2020; Xiang vd., 2020, s.228-229; ).

Son dönem dünya genelini etkisi altına alan ve bu alanda akademik çalışmaların odağında yer alan COVID-19 pandemisi ile ilişkili olarak yapılan araştırmalar incelendiğinde, hastalığa yakalanma korkusuyla birlikte yoğun endişelerin yaşanıldığ 1 görülmüştür. Ayrıca yaşanılan bu endişeler, bireylerin psikolojik iyi oluş hallerinde olumsuzluklara neden olmakla beraber insanların ruh sağlığını olumsuz yönde etkilendiğini göstermektedir (Ahmed 
ve diğ., 2020; Batigün ve Ertürk, 2020; Chen ve diğ., 2020; Erdoğdu ve diğ., 2020; Ho ve diğ., 2020; Okur ve Demirel, 2020; Qiu ve diğ., 2020; Sani ve diğ., 2020). COVID-19 süreci ile ilgili bilgilerin internet üzerinden paylaşılmasının olumsuz duygular olan anksiyete, depresyon, öfke ve sosyal risklere olan eğililimi anlamlı düzeyde arttığını, pozitif duyguları ise azalttığı belirtilmiştir (Li ve diğ., 2020). Bu görüşü destekler nitelikte Strong (1990)' da, virüs haberlerinin sıklıkla verilmesinin hasta olma korkusunu arttırdığını ifade etmiştir. Bekaroğlu ve Yilmaz (2020) 'a göre COVID-19- enfeksiyonu yaşayan ya da enfekte olduğundan şüphe duyulan hastaların Brooks ve diğ. (2020) ve Ornell, Schuch, Sordi ve Kessler (2020) çalışmalarında olduğu gibi korku, can sıkıntısı, yalnızlık, kaygı, uykusuzluk veya öfke gibi yoğun duygusal ve davranışsal tepkiler göstermektedirler.

Doğan ve Düzel (2020) yapmış olduğu araştırmada salgının Türkiye'de görüldüğü ilk haftalarda bireylerin aile yakınlarını kaybetme korkusu ve kalabalık yerlerden virüse maruz kalmaktan korktukları görülmüştür. Salgın sürecinde korku ve kaygı bir tepki olarak tüm bireylerde gözlenmekle birlikte, yaş, cinsiyet, eğitim, gelir düzeyi, çalışma koşulları ve yaşanılan çevreye bağlı olarak değişkenlik gösterebilmektedir. Çalışma, salgın konusunda erkeklerin kadınlara, ortaöğretim mezunlarının lisans mezunlarına oranla daha kaygılı olduğunu göstermektedir. Bu bağlamda cinsiyet ve eğitim düzeyinin bireylerin kaygı düzeyleri üzerinde farklılık yarattı̆̆ görülmektedir.

COVID-19 'un psikolojik olarak olumsuz etkileri konusunda yapilan çalışmalar incelendiğinde; C. Wang ve diğ. (2020) kronik hastalığı olanların salgını daha ağır bir şekilde geçirdiği sonucuna ulaşmıştır (Gencer, 2020). Rajkumar ve diğ. (2020) tarafından yapılan bir diğer araştırmada ise diğer araştırmaların bulgularını destekler biçimde salgının ortaya çıkışı ve vaka sayılarının arttı̆ 1 dönemlerde bireylerde artan düzeyde korku, endişe, stress ve kaygı algıladığını tespit etmişlerdir (Gencer,2020; Tönbül, 2020). Bu çalışmada, Kovid Kaygı Ölçeğini çeşitli değişkenler açısından incelenmesi amaçlanmaktadır. 


\section{Yöntem}

\section{Çalışma Grubu}

Ölçek çalışması 292 kişi üzerinde uygulanmıştır. Araştırma kapsamında örneklemin 181'i (\%62) kadın, 111'i (\%38) erkek bireyden oluşmaktadır. Örneklemde yer alan bireylerin; 126 'sı (\% 43) büyükşehirde; 166 'sı (\%57) ilçe-köyde yaşamaktadır. Ayrıca, araştırmaya katılan bireyler eğitim durumları açısından; 217 (\% 74) üniversite, 55 (\% 18) lise, 20 (\%6) ilkokulortaokul eğitimine sahiptir. Örneklemin yaş ortalaması 34.4' $(\mathrm{Std}=8.4)$ dir. Araştırmanın etik kurul izni, Aksaray Üniversitesi İnsan Araştırmaları Etik Kurulu tarafından 22.06.2020 tarihinde alınmıştır.

KOVID-19-Kaygı Ölçeği: KOVID-19- Kaygı Ölçeği Silva ve diğerleri (2021) tarafından kOVID-19 ile ilişkili kaygıyı ölçmek için geliştirilmiştir. Ölçek 7 maddeden oluşmakta ve tek boyutludur. Ölçekte yer alan maddeler dörtlü Likert tipi bir ölçekte puanlanmaktadır. Ölçek uyarlama sürecinde, psikolojik danışma alanından dört bağımsız akademisyen tarafından İngilizceden Türkçeye çevrilmiş ve yazarlar çevirileri karşılaştırarak fikir birliğine varmıştır. Ardından, Türkçe form üç bağımsız İngilizce uzmanı tarafından tekrar İngilizceye çevrildi. Son aşamada, dört araştırmacı da tüm maddeleri Türkçe ve İngilizce olarak gözden geçirerek herhangi bir anlamsal farkl1lığ tartışmıştır.

Ölçeği uyarlama çalışması kapsamında, Açımlayıcı Faktör Analizi (AFA) kullanılarak faktör yapısı incelenmiştir. $\mathrm{AFA}^{\prime} \mathrm{da}, 7$ maddenin tümü temel bileşenler faktörleme ve varimax rotasyonuna tabi tutulmuştur. KaiserMeyer-Olkin ve Bartlett' in küresellik değer testi anlamlıdır. Açıklanan toplam varyans $\% 69.00$ olarak hesaplanmıştır. Yedi maddenin faktör yükleri 0.62 ile 0.80 arasında değişmekte olup, her bir maddenin faktöre iyi ve mükemmel düzeylerde önemli ölçüde katkı sağladığını göstermektedir.

Ölçeğin yapısını doğrulamak amacı ile LISREL'de kullanarak tek boyutlu ölçüm modeli test edilmiştir. Varsayımlanan ölçüm modeli, Kabul edilebilir model uyumu sağlamıştır. Model uyum indeksleri; NNFI = .95, CFI = .97, IFI $=.97, \mathrm{SRMR}=.04, \mathrm{RMSEA}=.15$ olarak bulunmuştur. Bu değerler, kabul edilebilir bir veri uyumu düzeyini göstermektedir. 


\section{Bulgular}

\section{Madde Analizi ve Güvenirlik}

Kovid Kaygı Ölçeği maddelerinin korelasyon puanları .63 ile .82 aralığında değiştiği bulunmuştur.

Tablo 1. Kovid Kaygı Ölçeği Maddelerinin Korelasyon Puanları

\begin{tabular}{ll}
\hline Madde No & rjx \\
\hline 1 & .78 \\
2 & .72 \\
3 & .81 \\
4 & .82 \\
5 & .80 \\
6 & .77 \\
7 & .63 \\
\hline
\end{tabular}

Ölçeğin KMO ve Bartlett analiz sonuçları Tablo 2 de verilmiştir.

Tablo 2. KMO ve Bartlett's Testi

\begin{tabular}{lll}
\hline Kaiser-Meyer-Olkin Measure of Sampling Adequacy. &, 900 \\
Bartlett's Test of Sphericity & Approx. Chi-Square & 1495,744 \\
& df & 21 \\
& Sig. &, 000 \\
\hline
\end{tabular}

Kovid Kaygı Ölçeği Maddelerinin açıklanan toplam varyans puanları Tablo 3 de görülmektedir.

Tablo3. Açıklanan toplam varyans

\begin{tabular}{lllllll}
\hline & \multicolumn{3}{c}{ Initial Eigenvalues } & & \multicolumn{3}{c}{ Extraction Sums of Squared Loadings } \\
Component & Total & \% of Variance & Cumulative \% & Total & \% of Variance & Cumulative \% \\
\hline 1 & 4,865 & 69,502 & 69,502 & 4,865 & 69,502 & 69,502 \\
2 &, 653 & 9,326 & 78,829 & & & \\
3 & 446 & 6,370 & 85,199 & & & \\
4 &, 374 & 5,348 & 90,547 & & & \\
5 &, 272 & 3,884 & 94,431 & & & \\
6 &, 226 & 3,228 & 97,659 & & & \\
7 &, 164 & 2,341 & 100,000 & &
\end{tabular}

Extraction Method: Principal Component Analysis.

Kovid kaygı düzeyleri açısından araştırma kapsamında; cinsiyet;eğitim durumu ve yaşanılan yer değişkenleri arasında anlamlı düzeyde farklılıklar 
olup olmadığını tespit etmek Bağmsız Gruplar t-Testi ve Anova uygulanmiştır.

Kovid kaygı düzeyleri açısından cinsiyet değişkeni arasında anlamlı düzeyde farklılıklar olup olmadığını tespit etmek Bağmsız Gruplar t-Testi yapılmıştır. Analiz sonuçları Tablo 4 de yer almaktadır.

Tablo 4. Kovid Kaygı Ölçeği Puanlarının Cinsiyet Değ̌şkenine Göre Karşılaştırılmasına İlişkin Bağmsız Gruplar t-Testi Sonuçları

\begin{tabular}{llllllll}
\hline Değişken & Cinsiyet & $N$ & & Ss & $t$ & Sd & $p$ \\
\hline \multirow{2}{*}{ Kovid Kaygısı } & Kadın & 181 & 22.1 & 7.8 & \multirow{2}{*}{2.641} & \multirow{2}{*}{249} & \multirow{2}{*}{009} \\
& Erkek & 111 & 19.7 & 7.8 & & & \\
\hline
\end{tabular}

Kovid Kaygı düzeylerine göre erkek ve kadın katılımclar arasında Tablo 4'e göre anlamlı düzeyde bir farklılık olduğu anlaşılmaktadır ( $p=.009 ; p<.05)$. Tablo'ya göre kadınların $(\bar{X}=22,1)$ Kovid Kaygı ölçeğinden aldıkları puan ortalamaları erkeklerin $(\bar{X}=19,7)$ Kovid Kaygı ölçeğinden aldıkları puan ortalamalarından daha yüksektir $(t(249)=2,641, p<.05)$.

Kovid kaygı düzeyleri açısından eğitim durumu değişkeni arasında anlamlı düzeyde farklılıklar olup olmadığını tespit etmek ANOVA Testi yapılmıştır. Analiz sonuçları Tablo 5 de yer almaktadır.

Tablo 5. Kovid Kaygı Ölçeği Puanlarna İlişsin ANOVA Testi Sonuçlan

\begin{tabular}{lcclcl}
\hline & $\boldsymbol{N}$ & $\bar{X}$ & Std. Sapma & $\boldsymbol{F}$ & $p$ \\
\hline ilkokul-Ortaokul & 55 & 21.7 & 6.98 & & \\
Lise & 20 & 19.9 & 5.21 & 1.117 & .329 \\
Üniversite & 216 & 21.7 & 5.01 & & \\
\hline
\end{tabular}

Tablo 5'de eğitim durumları açısından araştırmaya katılan bireylerin Kovid kaygı puan ortalamaları, standart sapmalar ve ANOVA sonuçları verilmiştir. Araştırmaya katılan bireylerin kovid kaygısı puan ortalamalarına ilişkin anlamlı farklılık bulunmamaktadır. Kovid kaygı açısından araştırmaya katılan bireylerin eğitim durumlarının Tukey testi sonuçları Tablo 6 da görülmektedir. 
Tablo 6. Çoklu Karşılaştırma Tukey HSD

\begin{tabular}{|c|c|c|c|c|c|c|}
\hline \multirow[b]{2}{*}{ (I) Eğitim Durumu } & \multirow[b]{2}{*}{ (J) Eğitim Durumu } & \multirow[b]{2}{*}{ Mean Difference (I-J) } & \multirow[b]{2}{*}{ Std. Error } & \multirow[b]{2}{*}{ Sig. } & \multicolumn{2}{|c|}{ 95\% Confidence Interval } \\
\hline & & & & & Lower Bound & Upper Bound \\
\hline \multirow[t]{2}{*}{1} & 2 & 1,73636 & 2,08000 & 682 & $-3,1639$ & 6,6366 \\
\hline & 3 &,- 05000 & 1,86184 & 1,000 & $-4,4363$ & 4,3363 \\
\hline \multirow[t]{2}{*}{2} & 1 & $-1,73636$ & 2,08000 & 682 & $-6,6366$ & 3,1639 \\
\hline & 3 & $-1,78636$ & 1,20311 & ,300 & $-4,6208$ & 1,0480 \\
\hline \multirow[t]{2}{*}{3} & 1 &, 05000 & 1,86184 & 1,000 & $-4,3363$ & 4,4363 \\
\hline & 2 & 1,78636 & 1,20311 & ,300 & $-1,0480$ & 4,6208 \\
\hline
\end{tabular}

1= Illkokul-Ortaokul; $2=$ Lise $; 3=$ Üniversite

Kovid kaygı düzeyleri açısından yaşanılan yer değişkeni arasında anlamlı düzeyde farklılıklar olup olmadığını tespit etmek Bağmsız Gruplar t-Testi yapılmıştır. Anazliz sonuçları Tablo 7 da yer almaktadır.

Kovid Kaygısı Ölçeği Puanlarının Yaşanılan Yer Değşskenine Göre Karşılaştırılmasına İlişkin Bağmsız Gruplar t-Testi Sonuçları

Tablo 7. Kovid Kaygı Ölçeğinin Puanlarının Yaşanılan Yer Değişkenine Anova Testi Sonuçları

\begin{tabular}{llllclll}
\hline Değişken & Cinsiyet & $N$ & $\bar{X}$ & Ss & $t$ & Sd & $p$ \\
\hline \multirow{2}{*}{ Kovid Kaygisı } & Büyükşehir & 125 & 23.00 & 7.7 & \multirow{2}{*}{3.008} & \multirow{2}{*}{271} & \multirow{2}{*}{.003} \\
& Ilçe-Belde & 166 & 20.21 & 7.9 & & & \\
\hline
\end{tabular}

Kovid Kaygı düzeylerine göre katılımcıların yaşanılan yer değişkeni açısından Tablo 7'ye göre anlamlı düzeyde bir farklılık olduğu anlaşılmaktadır ( $p=.003 ; p<.05)$. Tablo 7'ye göre büyükşehirde yaşayanların $(\vec{X}=23,0)$ Kovid Kaygı ölçeğinden aldıkları puan ortalamaları İlçe-belde de yaşayanların $(\bar{X}=20,21)$ Kovid Kaygı ölçeğinden aldıkları puan ortalamalarından daha yüksektir $(t(271)=3,008, p<.05)$.

\section{Sonuç ve Tartışma}

Bu çalışmada, Kovid Kaygı Ölçeğinin çeşitli değişkenler açısından incelenmesi amaçlanmaktadır. Ölçeğin güvenirlik katsayılarının yüksek bulunması, güvenirliğin yeterli düzeyde olduğunu göstermektedir. Araştırmamız bulgularına göre kadınların COVID-19 salgınında erkeklere oranla daha fazla kaygı yaşamaktadır. Benzer sonuçlar Bakioğlu ve vd.(2020), Ekiz vd.( 2020), Kong vd., (2020),Kurt vd., (2020), Özdin ve Özdin, (2020), C. Wang vd., (2020), Erdoğdu, Koçoğlu ve Sevim (2020), Öz Ceviz ve vd(2020), Çölgeçen ve 
Çölgeçen (2020) ve Gencer(2020)'in çalışmalarında görülmektedir. Ayrıca sağlık alanında çalışan kadınlarda kaygı puanının erkeklere oranla daha yüksek olduğu da görülmüştür (Ocaktan, Keklik ve Çöl, 2002; Sakaoğlu ve vd.2020). Maaravi ve Heller (2020)' Birleşik Krallık'ta 407 kişiye yönelik gerçekleştirdiği çalışmada Kovid-19 sürecinde kadınların daha fazla kaygı yaşadığı sonucuna ulaşmışlardır. Tayvan'da Wong ve arkadaşlarının(2020) yapmış olduğu araştırmada da kadınların erkeklere göre Kovid -19 sürecinde daha fazla kaygı yaşadıkları sonucuna ulaşmışlardır( Çölgeçen ve Çölgeçen, 2020). Eğitim düzeyine göre Kovid -19 un kaygı oluşturma düzeyleri incelendiğinde ise eğitim düzeyleri arasında anlamlı farklılığın olmadığ1 görülmüştür. Eğitim durumuna göre kayg1 durumuna bakıldığında, durumluk ve sürekli kaygı puanları arasında fark saptanmamıştır. Öğrenim düzeyi düşük olan kişilerde, kaygı düzeylerinin yüksek olması beklenmekte olup, kaygı düzeyi ile ilgili yapılan birçok araştırma neticesi bunu desteklemektedir (Sakaoğlu ve diğ.2020). Bakioğlu ve diğ.(2020), Ekiz ve diğ. (2020)'nin yapmış olduğu benzer çalışmalar incelendiğinde de aynı sonuçlar görülmektedir.

Araştırma bulgularından bir diğeri ise bireylerin Kovid-19 salgınında yaşamış oldukları kaygı düzeyleri ile yerleşim yerleri arasındaki ilişkiyi saptamaktı. Elde edilen bulgulara göre il ve ilçe merkezlerinde yaşayan bireylerin köy ve kasabada yaşayan bireylere göre kaygı düzeylerinin daha yüksek olduğu görülmüştür. Ancak Artan ve diğ. (2020) tarafından yapılan araştırmada ise yerleşim yerine göre bireylerin kaygı yaşamadıkları görülmüştür. Büyük şehirlerde yaşayan bireylerin kırsal alana göre daha fazla kaygı yaşaması çok yönlü etkenlere bağlı olarak değerlendirilebilir. Bu etkenleri kırsal alanda yaşayan nüfusun ağırlıklı olarak yaşlı nüfus olması, bilgi iletişim imkânlarının yeterli olmaması, eğitim düzeylerinin düşük olması, günlük kırsal alan aktivitelerinin yoğunluklu olması kırsal alan sakinlerinin COVID-19'un etkisini araştırmamalarına ve bu konu üzerinde düşünmemelerine neden olabilir. 


\title{
EXTENDED ABSTRACT
}

\section{Examining COVID-19 Anxiety in Terms of Various Variables}

\author{
* \\ Serhat Arslan- Savaş Karagöz- Nihan Arslan \\ Necmettin Erbakan University-Aksaray University-Necmettin Erbakan University
}

In the historical process, human beings have been faced with negative events such as wars and epidemics, which call disasters in general terms from the day they existed. In such cases, it has become inevitable to experience psychological anxiety, stress and anxiety. Anxiety, which corresponds to the concept of anxiety in English, is defined as "the uneasiness of individuals in the face of the possibility of not realizing any strong desires or motives of social groups. Epidemics have been periods when many distressing emotions were experienced intensely. Intense negative emotions can lead to an increase in existing mental problems or to the emergence of mental problems that did not exist before. Emotions and specific situations that are difficult to cope with can be counted as intolerance to uncertainty and uncertainty, isolation, staying away from emotional sharing, fear, loneliness, anxiety, sadness, and stigmatization. According to Kandemir and Atak, who stated that one of the most common problems that can arise in periods when human life is negatively affected, anxiety is also a problem that arises with negative thoughts in our minds. As concerns about many things are seen in our daily lives, these concerns also arise against the coronavirus, which negatively affects a large community around the world.

When the researches related to the COVID-19 pandemic, which has recently affected the whole world that seen that intense concerns are experienced with the fear of contracting the disease. In addition, these concerns show that people's mental health is adversely affected, as well as causing negativities in the psychological well-being of individuals. It has been stated that sharing information about the COVID-19 process over the internet significantly increases the tendency to negative emotions such as anxiety, depression, anger and social risks, and decreases positive emotions.

In this study, it was aimed to adapt the Covid Anxiety Scale developed by Silva et al. (2021) to Turkish culture. EFA and DFA were used to test 
the construct validity of the comments made from the "COVID-19 Anxiety" measurements. Findings obtained in EFA and CFA showed that the fit indexes of the single factor structure related to the scale were sufficient. The groups in which validity and reliability studies were carried out are sufficient enough for statistical analysis in terms of number. The high reliability coefficients of the scale indicate that the reliability is at a sufficient level.

According to the findings of the research, women experience more anxiety than men in the COVID-19. Similar results are Bakioğlu et al. (2020), Ekiz et al. (2020), Kong et al., (2020), Kurt et al., (2020), Özdin \& Özdin, (2020), C. Wang et al., (2020), Erdoğdu, Koçoğlu and Sevim (2020), Öz Ceviz and et al (2020), Çölgeçen and Çölgeçen (2020) and Gencer (2020). In addition, it was observed that the anxiety score of women working in the health field was higher than that of men (Ocaktan, Keklik, \& Çöl, 2002; Sakaoğlu et al. 2020). Maaravi and Heller (2020) concluded in their study of 407 people in the UK that women experienced more anxiety during the COVID-19 process. In the study conducted by Wong et al. (2020) in Taiwan, they found that women experienced more anxiety during the COVID-19 process than men (Çölgeçen and Çölgeçen, 2020). When the anxiety levels of COVID-19 were examined according to the education level, it was seen that there was no significant difference between the education levels. Considering the anxiety level by education level, no difference was found between state and trait anxiety scores. People with low education levels are expected to have high levels of anxiety, and many research results on the level of anxiety support this (Sakaoğlu et al. 2020). The same results are seen when similar studies by Bakioğlu et al. (2020), Ekiz et al. (2020) are examined.

Another of the research findings was to determine the relationship between the anxiety levels that individuals experienced in the COVID-19. According to the findings, it was observed that individuals living in city and district centers had higher anxiety levels than those living in villages and towns. It was observed that individuals did not experience anxiety depending on the place of residence. The fact that individuals living in big cities experience more anxiety compared to rural areas can be evaluated due to multifaceted factors. These factors may cause rural residents not to investigate the effect of COVID-19 and not to think about the effect of the 
rural population, mainly the elderly population, the lack of information communication opportunities, low education levels, and intensity of daily rural activities.

\section{Kaynakça/References}

Ahmed, M. Z., Ahmed, O., Aibao, Z., Hanbin, S., Siyu, L. ve Ahmad, A. (2020). Epidemic of COVID-19 in China and associated psychological problems. $\begin{array}{llll}\text { Asian Journal of Psychiatry, 51, } & \text { 1-7. }\end{array}$ https://doi.org/10.1016/j.ajp.2020.102092

Ahorsu, D. K., Lin, C. Y., Imani, V., Saffari, M., Griffiths, M. D. ve Pakpour, A. H. (2020). The Fear of COVID-19 Scale: Development and initial validation. International Journal of Mental Health And Addiction, Brief Communication 1-9. Advance Online Publication. https://link.springer. com/ article/ 10.1007/s11469-020-00340-x. Erişim taihi: 25.07.2021.

Artan, T., Atak, I., Karaman M. ve Cebeci, F. (2020). Koronavirüs (COVID-19) salgınında sosyodemografik özellikler, psikolojik sağlamlık ve kaygı düzeyleri arasındaki ilişki. Turkish Studies, 15(6), 79-94. https://dx.doi.org/10.7827/TurkishStudies.43882

Bakioğlu, F., Korkmaz, O. ve Ercan, H. (2020). Fear of COVID-19 and positivity: mediating role of intolerance of uncertainty, depression, anxiety, and stress. Int J Ment Health Addiction, 1- 14. https://link.springer.com/ article/ 10. 1007\%2Fs11469-020-00331-y . Erişim tarihi: 21.07.2021.

Banerjee, D. (2020). The COVID-19 outbreak: Crucial role the psychiatrists can play. Asian J. Psychiatr, 50, 102014.

Bekaroğlu, E. ve Yılmaz, T. (2020). COViD-19 ve psikolojik etkileri: Klinik psikoloji perspektifinden bir derleme. Nesne, 8(18), 573-584. DOI: 10.7816/nesne-08-18-14.

Bingül Ak, B., Türk, A. ve Ak, R. (2020). COVID-19 bağlamında tarihteki büyük salgınlar ve ekonomik sonuçları. Turkish Studies, 15(4), 189-200. https://dx.doi.org/10.7827/TurkishStudies.44242

Brooks, S. K., Webster, R. K., Smith, L. E., Woodland, L., Wessely, S., Greenberg, N. ve Rubin, G. J. (2020). The psychological impact of quarantine and how to reduce it: Rapid review of the evidence. The Lancet, 395(10227), 912-920. doi:10.1016/S0140-6736(20)304 
Cao, W., Fang, Z., Hou, G., Han, M., Xu, X., Dong, J. ve Zheng, J. (2020). The psychological impact of the COVID-19 Epidemic on college students in China. Psychiatry Research, 287(112934), 1- 5.

Chen, Q., Liang, M., Li, Y., Guo, J., Fei, D., Wang, L., He, L., Sheng, C., Cai, Y., Li, X., Wang, J. ve Zhang, Z. (2020). Mental health care for medical staff in China during the COVID-19 outbreak. The Lancet Psychiatry, 7(5), 15-16. https://doi.org/10.1016/S2215-0366(20)30164-4.

Çölgeçen, Y. ve Çölgeçen, H. (2020). COVID-19 pandemisine bağlı yaşanan kayg1 düzeylerinin değerlendirilmesi: Türkiye örneği. Turkish Studies, 15(4), 261-275. https://dx.doi.org/10.7827/TurkishStudies.44399

Durak Batıün, A. ve Şenkal Ertürk, İ. (2020). Çok Boyutlu COVID-19 Ölçeği geliştirme, geçerlik ve güvenirlik çalışması. Nesne, 8(18), 406-421. DOI: 10.7816/nesne-08-18-04.

Ekiz, T, Ilıman, E. ve Dönmez, E. (2020). Bireylerin sağlık anksiyetesi düzeyleri ile COVID-19 Salgını kontrol algısının karşılaştırılması. Usaysad Dergisi, 6(1), 139-154.

Erdoğdu, Y., Koçoğlu, F. ve Sevim, C. (2020). COVID-19 pandemisi sürecinde anksiyete ile umutsuzluk düzeylerinin psikososyal ve demografik değişkenlere göre incelenmesi. Klinik Psikiyatri Dergisi, 23(Ek 1), 24-37. https://doi.org/10.5505/kpd.2020.35403.

Gencer, N. (2020). Pandemi sürecinde bireylerin Koronavirüs (Kovid-19) korkusu: Çorum örneği. USBAD Uluslararası Sosyal Bilimler Akademi Dergisi 2(4), 1153-1173.

Ho, C. S. H., Chee, C. Y. I. ve Ho, R. C. M. (2020). Mental health strategies to combat the psychological impact of COVID-19 beyond paranoia and panic. Annals, Academy of Medicine, Singapore, 49(1), 1-6.

https:// www. solunum. org.tr/ TusadData/Book/881/131020201683-bolum12.pdfErişim tarihi.25.07.2021.

https://www.instagram.com/druamkku/ Erişim tarihi: 20.8.2021.

Kong, X., Zheng, K., Tang, M., Kong, F., Zhou, J., Diao, L. ve Yuchao, D. (2020). Prevalence and factors associated with depression and anxiety of hospitalized patients with COVID-19. MedRxiv, 2020, 1-12.

Kurt, O., Deveci, S. E. ve Oguzoncul, A. F. (2020). Levels of anxiety and depression related to COVID-19 among physicians: An online cross-sectional study from Turkey. Annals of Clinical and Analytical Medicine, 11(1), 283-293.

Li, S., Wang, Y., Xue, J., Zhao, N. ve Zhu, T. (2020). The impact of COVID-19-19 epidemic declaration on psychological consequences: A study on active 
Weibo users. International Journal of Environmental Research and Public Health, 17(6), 1-9. https://doi.org/10.3390/ijerph17062032

Maaravi, Y. ve Heller, B. (2020). Not all worries were created equal: The case of COVID-19-19 Anxiety. Public Health 185, 243-245. https://doi.org/10.1016/j.puhe.2020.06.032 Ocaktan, M. E., Keklik, A. ve

Mamun, M. A. ve Griffiths, M. D. (2020). First COVID-19 suicide case in bangladesh due to fear of COVID-19 and xenophobia: Possible suicide prevention strategies. Asian Journal of Psychiatry, 51,(102073), https://www. sciencedirect. com/ science/ article/abs/ pii/ S1876201820301842? via\%3Dihub

Memiş Doğan, M. ve Düzel, B. (2020). COVİD-19 özelinde korku-kayg1 düzeyleri. Turkish Studies, 15(4), 739-752.

Ocaktan, M. E., Keklik, A. ve Çöl, M. (2002). Abidinpaşa Sağlık Grup Başkanlığı'na bağlı sağlık ocaklarında çalışan sağlık personelinde Spielberger durumluluk ve sürekli kaygı düzeyi. Ankara Üniversitesi Tıp Fakültesi Mecmuası, 55(1), 21-8.

Okur, İ. ve Demirel, Ö. F. (2020). COVİD-19 ve psikiyatrik bozukluklar. Medical Research Reports, 3(Supp 1), 86-99.

Ornell, F., Schuch, J. B., Sordi, A. O. ve Kessler, F. H. P. (2020). Pandemic fear and COVID-19: Mental health burden and strategies. Brazilian Journal of Psychiatry, (AHEAD), 42(3), 232-235. doi:10.1590/1516-4446- 2020-0008

Öz Ceviz, N., Tektaş N., Basmacı G. ve Tektaş, M. (2020). COVID-19 pandemi sürecinde üniversite öğrencilerinin kaygı düzeylerini etkileyen değişkenlerin analizi. Uluslararası Eğitim Araştırmacıları Dergisi, 3(2), 312329

Özdin, S. ve Özdin, Ş. B. (2020). Levels and predictors of anxiety, depression and health anxiety during COVID-19 Pandemic in Turkish Society: The importance of gender. International Journal of Social Psychiatry 66(5), 504-511.

Qiu, J., Shen, B., Zhao, M., Wang, Z., Xie, B. ve Xu, Y. (2020). A nationwide survey of psychological distress among Chinese people in the COVID-19 epidemic: Implications and policy recommendations. General Psychiatry, 33(2), 1-3. https://doi.org/10.1136/gpsych-2020-100213

Rajkumar, R. P. (2020). COVID-19 and mental health: A review of the existing literature. Asian Journal of Psychiatry, 52(2020). https://doi.org/10.1016/ j.ajp.2020.102066

Sakaoğlu H.H., Orbatu D., Emiroglu M. ve Çakır Ö. (2020).COVID-19 salgını sırasında sağlık çalışanlarında spielberger durumluk ve sürekli kaygı 
düzeyi: Tepecik hastanesi örneği. Tepecik Ĕ̆it. ve Araşt. Hast. Dergisi, 30(Ek sayı), 1-9.

Sani, G., Janiri, D., Di Nicola, M., Janiri, L., Ferretti, S. ve Chieffo, D. (2020). Mental health during and after the COVID-19 emergency in Italy. Psychiatry and Clinical Neurosciences, 74, 372-373. https://doi.org/10.1111/pcn.13004.

Silva, W. A. D., Brito, T. R. S. ve Pereira, C. R. (2021). Anxiety associated with COVID-19 and concerns about death: Impacts on psychological well-being. Personality and Individual Differences, 176(2021).110772.https:// doi.org/10.1016/j.paid.2021.110772.

Strong, P. (1990). Epidemic psychology: A model. Sociology of Health $\mathcal{E}$ Illness, 12(3), 249-259.

Tönbül, Ö. (2020). Koronavirüs (COVID-19) Salgını sonrası 20-60 yaş arası bireylerin psikolojik dayanıklılıklarının bazı değişkenler açısından incelenmesi. Uluslararası Akademik Psikolojik Danışma ve Rehberlik Araştırmaları Dergisi, 2(2), 159-174.

Wang, C., Pan, R., Wan, X., Tan, Y., Xu, L., Ho, C. S. ve Ho, R. C. (2020). Immediate psychological responses and associated factors during the initial stage of the 2019 coronavirus disease (COVID-19) epidemic among the general population in China. International Journal of Environmental Research and Public Health, 17(1729), 1-25.

Wong, L. P., Hung, C. C., Alias, H. ve Lee, T. S. (2020). Anxiety symptoms and preventive measures during the COVID-19 outbreak in Taiwan. BMC Psychiatry, 20, 376. https://doi.org/10.1186/s12888-020-02786-8

Xiang Y-T, Yang Y, Li W, Zhang L, Zhang Q, Cheung T et al. (2020) Timely mental health care for the 2019 novel coronavirus outbreak is urgently needed. Lancet Psychiatry, 7, 228-229.

\section{Kaynakça Bilgisi / Citation Information}

Arslan, S., Karagöz, S. ve Arslan, N. (2021). KOVİ-19 kaygısının çeşitli değişkenler açısından incelenmesi. OPUS-Uluslararası Toplum Araştırmaları Dergisi, 18(43), 6280-6294.

DOI:10.26466//opus.943710. 